\title{
The Internationalisation of a Public University Through International Internships. Students Opinion
}

\author{
Josep Alemany, Xavier Parramon, M. Pilar Curós
}

\begin{abstract}
This work studies the effects of international internships on the employability of recent graduates of a public South European university, the type of employment achieved and the relationship with the knowledge and skills acquired during the internships.A survey was conducted during the international internship and a new survey has been administered one year later in order to follow the situation immediately after the internship and after a few years in terms of employability. This survey includes different aspects such as: relationship between theory and current job, type of employment and labour contract, and soft skills used in the current work. The expected results show the relationship between the international internships and the graduate international employability.
\end{abstract}

Keywords : International internships, employability, survey, Higher Education, soft skills acquired, Erasmus Practicum.

\section{INTRODUCTION}

According to the EU youth strategy (European Commission, 2017), youth work and non-formal learning play an important role in developing the creative and innovative potential of young people including entrepreneurial skills. Two special programmes are related to the topic of this paper: one is to ensure educators and employers being aware of the value of a non-formal learning, and the second one is the Erasmus+ programme focused on innovation and entrepreneurship based on international internships. The main aim of internationalization in higher education is to make sure the future workforce develops the necessary intercultural competencies to function in a globalized economy (Vriens et al., 2011).

The work presented here is part of a research about the deployment of post-EHEA traineeships and their internationalisation at Universitat Pompeu Fabra (UPF), which in turn opens a novel line of research at the European level on internationalisation strategies for universities that has not been extensively studied until now. In order to consolidate the university's own teaching model, UPF proposes to meet the requirements of a demanding and evolving environment through 7 proposals, two of which are: a) internationalise the classrooms with measures such as bringing in new contents in the subjects, fostering oral and written proficiency in the three university languages as well as other foreign languages besides English, and promoting

Revised Manuscript Received on July 22, 2019

Josep Alemany, Xavier parramon, M. Pilar Curós linguistic and cultural diversity in all educational areas; and b) provide more support to labour insertion, with a wider range of curricular and extracurricular placements, and a personalised accompaniment for students in their process of acquiring professional competences as well as their labour integration. The combination of these two proposals is our base to understand that internationalisation more than satisfies both teaching demands mentioned above. Internationalisation is realised not only with the study of foreign languages but also with international mobility programmes and, more recently, with the development of practices abroad in the framework of the Erasmus+ Practices programme or through bilateral agreements under the sponsorship of the Professional Careers Service at UPF.

This work intends to study the effects of international internships on the employability of recent graduates of UPF, the type of employment achieved and the relationship with the knowledge and skills acquired during the internships. Results show the usefulness of internships.

\section{THEORETICAL BACKGROUND AND STATE OF THE ART}

The theoretical background of internships is based on constructivism and Kolb's Experiential Learning Cycle (Kosnik et al., 2013), and on Vygotsky's (1980) socio-economic influence theories. International traineeships are a case where Kolb's Experiential Learning Cycle is developed. The continuous process of knowledge and learning based on individual experiences and interactions with the environment is enhanced with socio-cultural aspects since the student may have to adapt to a new cultural context, a new language, and develop intercultural skills. Active experimentation is complemented in a balanced way with an intensive-reflexive observation of the acquired experience, because for international internships the environment is more influential. On the other hand, Vygotsky in his sociocultural theory understands that the culture affects the learner in interpersonal and cultural aspects, including the effects of the language acquisition because the language is developed from the social interactions and is the major human skill to communicate to the external world.

To the best of our knowledge there is not a big amount of literature on international internships, even though this is considered as a high relevant topic in the academia. For many students an international internship is more interesting

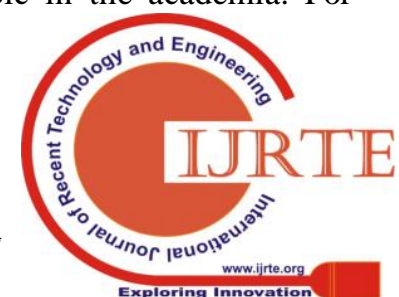


than a mobility, and many employees are willing to recruit students with international working experience.

Although there is a limited number of studies on this topic, three threads emerging from the state-of-the-art research on international internships can be identified in the current literature: the opportunities for intercultural skill development, integrating theory or course work with international practices, and preparation for employment or career aspirations in a globalised context.

Several authors (Deakin, 2012, Tran and Soejatminah, 2017) hold that work placement mobility also reinforces globalisation by encouraging the mobility of individuals after graduation, leading to subsequent highly skilled migration of future workers. As stated by Deakin (2012), completing an international internship provides a combination of experiences, both international experience and employability skills, that can give the graduate the required distinction from peers and highlights that work placement mobility is very different to study abroad in numerous ways.

In her study, Deakin (2012), after analysing the students mobility concepts, drivers, barriers and experiences, poses three research questions, the aims of which are: (1) to examine the drivers of Erasmus work placement mobility for UK students, (2) to explore how UK students experience an Erasmus work placement in industry, and (3) to examine students' perceptions of the effects of taking part in an Erasmus work placement (personally, professionally and future plans). The results achieved through a qualitative research including deep interviews are:

1) Employability, failure to secure a placement in the UK, language, finance and personal and biographical factors emerge as important drivers to mobility. The importance of these drivers does, however, vary according to factors such as gender, course type and language skills.

2) The research argues that socialisation and contact with locals is more common amongst students who work abroad as opposed to study, mainly due to the way accommodation and integration in the workplace is realised. Overall, the Erasmus work placement experience is found to be positive, and where problems are faced, they are seen as positive for personal development.

3) The effects are wide reaching with students believing their time abroad to have greatly affected their lives in numerous, interlinked ways. Overall, students view the effects of their mobility as positive, and often life changing.

On the other hand, Capa (2016), citing previous works including Deakin (2012), compares national and international internships and reviews the literature on this topic, and affirms that interpersonal skills and learning capacity are the most valuables skills during Higher Education. These features are maintained in international internships.

Two other works contain a literature review on the topic. In one of them, Zhang (2012) explains the intercultural competences and their relationship with international internships, and the important functions of international internships for Chinese students: intercultural communicative skills, international working experience and intercultural understanding.

In the second one, Sanahuja and Ribes (2014) elaborate a literature review of internships for business students, from 360 peer-reviewed articles, which include 57 relevant internship program researches. They make a specific reference to international internships which play a pivotal role in improving intercultural competencies, and there are: intercultural communicative skills, intercultural work experience and intercultural understanding, and these three aspects appear to be improved after the international internship experience. According to this review, most of the studies deal with participants satisfaction, their expectations and perceptions of internships. They evidence in their conclusions the lack of empirical research concerning business internships in the European context, and finalise their article with the need to investigate the actual effects of internships based in measurable data because most studies are based on participants' perceptions.

International internships are normally placed on one of three categories (Toncar and Cudmore, 2000): foreign study tours, short duration internships (no longer than one full semester) and long duration internships (longer than one semester). Nowadays, the first category practically has disappeared. The difference between short and long duration makes sense because of the effects of the socio-cultural influences. Additionally a recent important categorisation could be included: the remuneration. As an example of the importance of this topic, the Bureau of the European Parliament agreed very recently (July 2018) to revise the internal rules on internships and their working conditions, in order to be comparable to those of the Robert Schuman Program and to be remunerated decently (Youthforum.org, 2018).

Deakin's study follows the definition offered by Nolting et al. (NAFSA, 2014, p. 2), whereby: "an international internship typically refers to a short-term (one month to one year) work experience with an organization abroad that allows participants to apply theoretical classroom knowledge in a real-world setting, and gain a better understanding of a given field in a global context. These international internships may or may not offer academic credit and may or may not be paid."

Research has been giving prominence to the enhancement of international competencies as a predictor of individual career success on a gradually universal marketplace (Cao et al., 2012). Further research carried on companies that host internship experiences display that a professional experience abroad is more professionally qualifying than studying abroad (Talaba and Lache, 2010). In general, work experience stated on the applicant's resumés seems to be positively correlated with the recruiters' assessments of applicants' employability (Cole et al., 2007) and further influences positively the hiring decisions (Hakel et al.,1970).

Accordingly, Knouse (1994) showed, through the manipulation of résumés, that recruiters are more likely to hire applicants with irrelevant education but work experience 
than the opposite. Similarly, Cole et al. (2007) concluded that US recruiters give the highest mean ratings to work experience followed by academic qualifications and extracurricular activities. Even for entry-level jobs, experience is one of the key qualifications sought of college graduates, and internships are one of the best ways for ambitious students to gain this experience (Gault et al., 2000). Interns can enjoy significant early career advantages over students who have not completed an internship (Gault et al., 2000).

\section{OBJECTIVES}

The objectives of this work are: a) to know the effect of the international practices in terms of type of employability, type of offers, and b) to analyse the relationship between the international internships and the current job. Additionally we analyse information about the companies and characteristics of the students.

\section{METHODOLOGY}

The research analysis is performed by the study of the participants of the Erasmus+ Practices programme during the period 2012-2017. An e-survey was conducted to all UPF students that participated in the Erasmus+ Practices and Professional Careers Service during this period. The conducted survey includes the following five groups of items:

1. Objective items. a) Gender, degree/masters studies. b) Type, location and size of company. c) Remuneration and length of the internship. d) Average grade of the studies. e) Date of finalization of the internship.

2. Employability process items. a) Situation at the end of the internship and its length: labour contract offered, practices extension offered, or no offer. b) Current situation: working, still doing an internship or searching for a job.

3. If the current situation is employed. a) Is the contract permanent or temporary. b) Is the company local, national or European. c) Is the graduate self-employed or working for their own company. d) Is the same company as in the internship.

4. Subjective items. a) Connexion between studies and current work. b) Usefulness of international internship in finding the current work. c) Global self-assessment of the internship done..

5. Three open questions. a) Most remarkable input that the knowledge of international companies contributed to the training, for example, languages, international company culture and organization, meeting colleagues from other cultures, etc. b) The main contribution to the company in which the practices were done, for example, different point of view to solve problems, business contacts, relationship to own country, etc. c) Any further comment or suggestion.

The questions in the survey were based on works investigating education in the workplace (Tynjälä, 2008, Virtanen et al., 2012), competences (Knipprath and De Rick, 2014), connective models between learning and practice (Griffiths and Guile, 2003), and own elaboration.

\section{RESULTS}

The survey was sent to 189 students (227 submitted, 38 bounced back) from all the degrees and masters of UPF, participating in the Erasmus+ Practices programme during the period 2012-2017. We received 48 responses (25\% of our sample), after re-sending the questionnaire four times. We need to admit that most of the students could not receive the survey, many of them are not related to the UPF Alumni list or do not check it regularly. One of the items in the survey asked about the date of the internship and half of the respondents affirmed that they finished the internship less than one year before the survey. On the other hand, this response rate, although low, is within the usual range for online surveys (Pan, 2010, Sheehan and McMillan, 1999).

The main characteristics observed from the responses are presented below, categorised in four groups: personal and objective items, internships and employability, characteristics of employment for those who are employed, and perceptions and assessment.

After the summary of the individual responses, some considerations are made about the interrelations between the most significant variables. Finally, the responses to the open questions are analysed.

\section{A. Objective items}

Personal and objective items include the following aspects: a) Gender, degree/masters studies. b) Type, location and size of company. c) Remuneration and length of the internship. d) Average grade of the studies. e) Date of finalization of the internship. We wanted to know if any of these items affects the employability of the students.

\section{Gender, degree/masters studies}

For the gender item, more than two thirds of the respondents were female $(66,7 \%)$ and one third male $(33,3)$. See Figure 1 below.

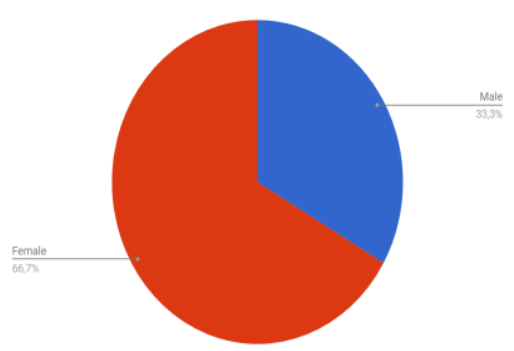

Figure 1. Gender item

The studies of the respondents were: Life and Health Sciences which were the largest group, followed by Economics and Business, and Political and Social Sciences. Humanities was the smallest group, followed by Engineering, Law and Communication. See Figure 2 below.

The distinction between studies is significant because some of them have their own specificities at UPF. The admission scores for Life and Health Sciences and for Economy and Business are among the topmost in the Catalan university system, and these are the degrees with the highest numbers of Erasmus internships.

This can be expected from the Economy and Business degree

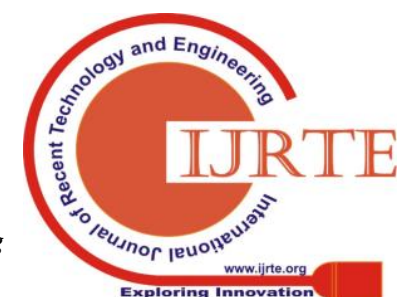


because it is the most populated at UPF, but it is quite remarkable for the Life and Health Sciences degree as the number of students is much smaller, but with a very high admission score, and with a deep interest in doing laboratory practices.

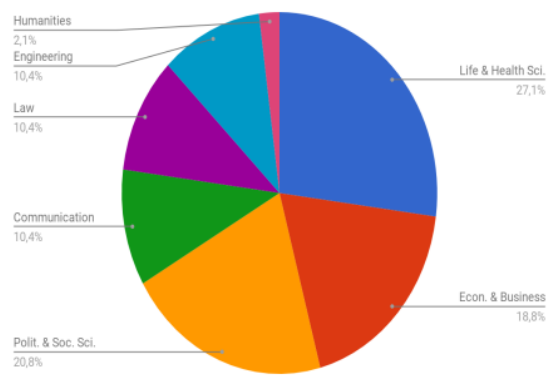

Figure 2. Studies of the internship participants

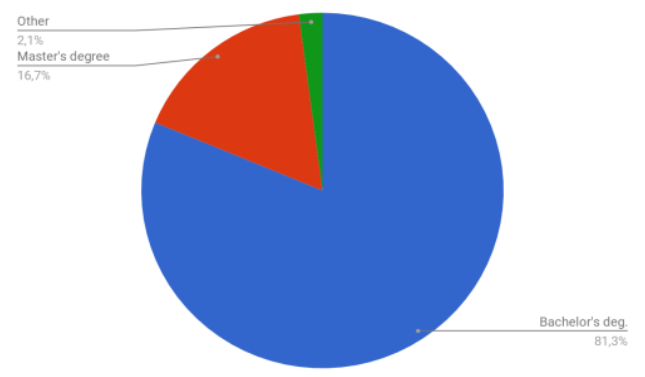

Figure 3. Type of studies

\section{Type, location and size of company}

A second group of items is related to the characteristics of the company or institution hosting the internship.

The aim is to know if the characteristics of the companies affect the student's satisfaction and if they have any influence on the employability of the students. In a previous study (Alemany, Perramon and Panadès, 2014) we found that large companies are more inclined to hire former trainees than small ones. Also, the effects of the economic crisis in Spain may have had a higher impact for SMEs, which have needed an important effort for recovering and keeping up.

The aspects more related to the features of the companies involved in this survey were the origin of the company and the type of company or institution, taking into account the distinction between private companies and public administrations.

About the origin of the company, the survey asked whether it is from the EU or extra-EU. Three out of four international internships were done in a company from the EU. See Figure 4 relating to the origin of the companies chosen by the students to do the internship.

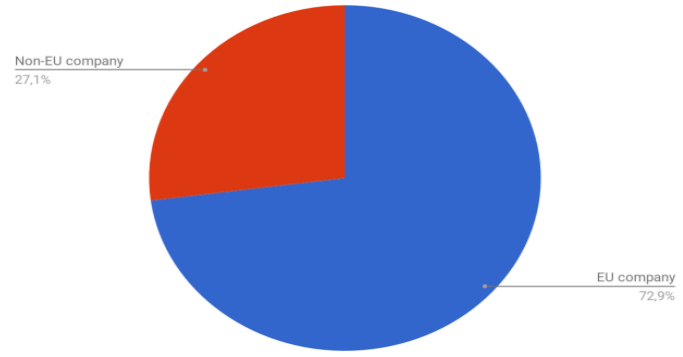

Figure 4. Origin of the company: EU or non-EU
Germany is the EU country where most international internships were done. It is followed by France, UK, Italy and USA, with Sweden in a lower position. Switzerland, Denmark, Holland, Ireland, Portugal and Spain were chosen only by 1 student. Other destinations were chosen by 11 students without further specification. See Figure 5 below.

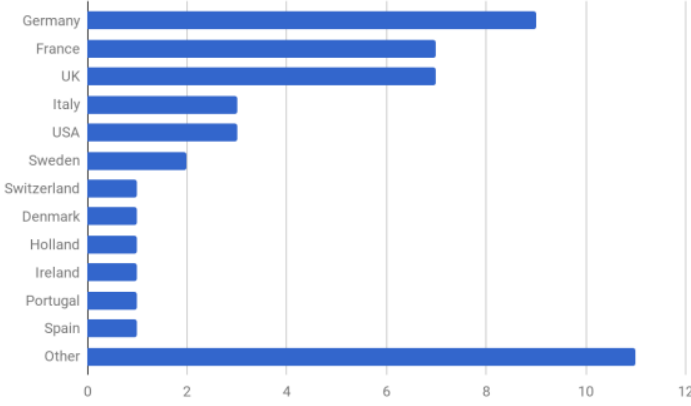

Figure 5. Countries chosen by the students

In relation to the type of the company, only one sixth of the international internships were done in a multinational company, around $15 \%$. For the Faculty of Economics and Business this is a relevant point because it helps students to access multinational companies job. See Figure 6 below.

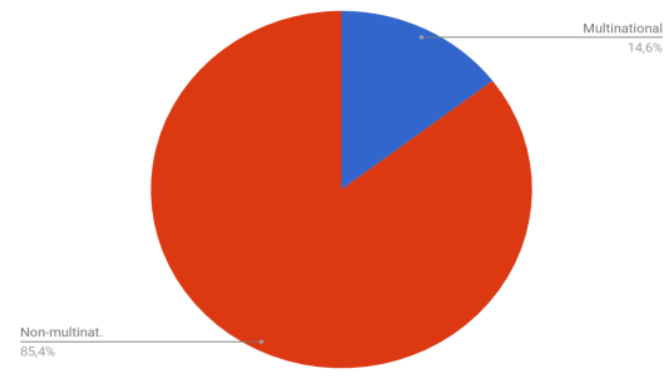

Figure 6. Type of company

Three out of five respondents $(60,4 \%)$ said the internship was done in a public administration. It is to be taken into account that for Political Science students and for Law students, Public Administration is a relevant employment target. See Figure 7 for results for this item.

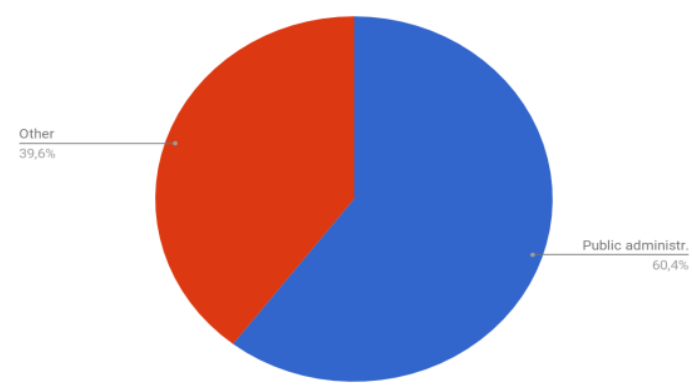

Figure 7. Internships in Public Administration

\section{Remuneration and length of the internship}

An important item nowadays, (for example in ....) is the remuneration of the internships. Had to be paid a work done by well educated students? Has a real value a work after the first month of work? Are these

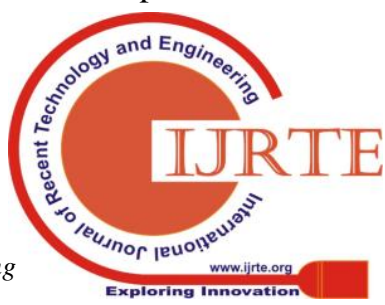


students the capacity of generating value to the company? Have they the opportunity to done it? How can this affect to the company results? Etc.

The first item was to know if the internship was or not remunerated. In the three free open questions the students were included this topic and shown that is an important worry.

The results of the survey, show, in relation to the remuneration of internships that only two out of five internships were paid. Taking into account that in some faculties, for example Economics and Business, all the internships have to be remunerated, while in others there is no regulation. See the result in Figure 1.4, below.
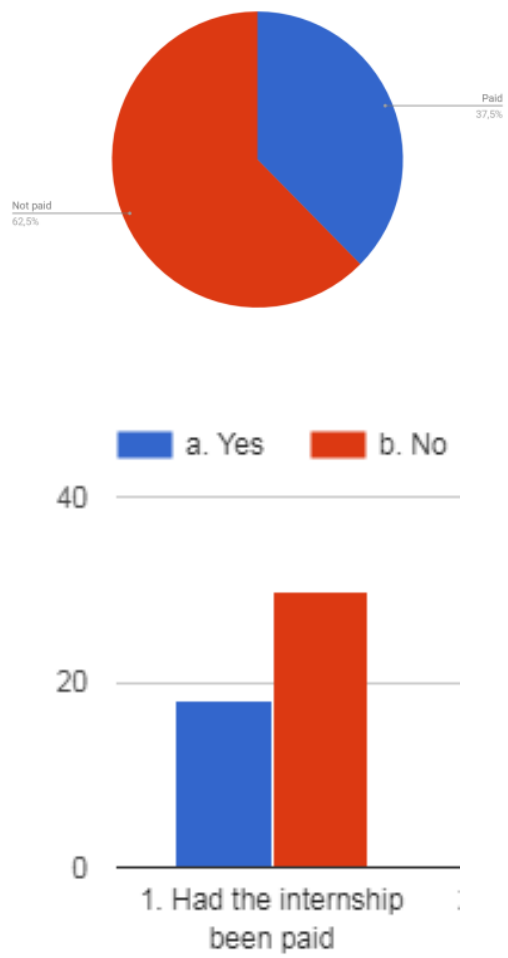

Figure 8. Internships remuneration

In relationship of the duration of the internship, most internships were 6 months or shorter. This is not an inconsequential question. It is demonstrable that as long is the duration more possibilities of employment are. Maybe because the student is more integrated or the company or the managers know better the student's capacities. The cost of being abroad for an international internship is not affordable for all the students specifically if they do not have any grant for a long duration one. See Figure1.5 below.

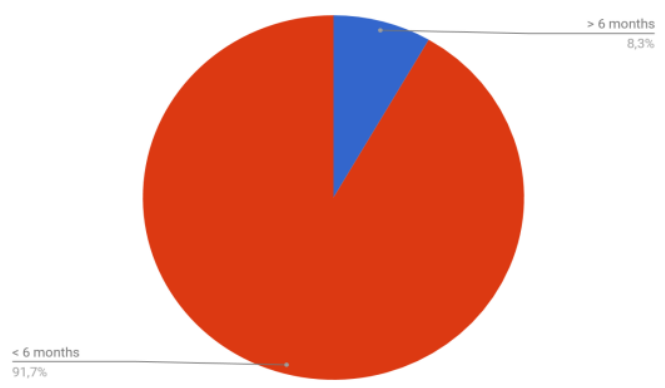

Figure 9. Duration of the internship

The access to the International Internship Program was done by different options. The most remarkable were by the Erasmus + Practicum Programme. Quite half of the international internships were done through this via. Professional Career Service at UPF did the $40 \%$ and the rest $(10 \%)$ were done by themselves. The rest, "other" in the e-survey were done by Spanish Ministry of Foreign Affairs, Internship from a company and by the UP-Campus site (that means by PCS at UPF). This question was interesting because the big implications of the administrative staff at the beginning of the process were remarkable. See Figure 1.10 below.

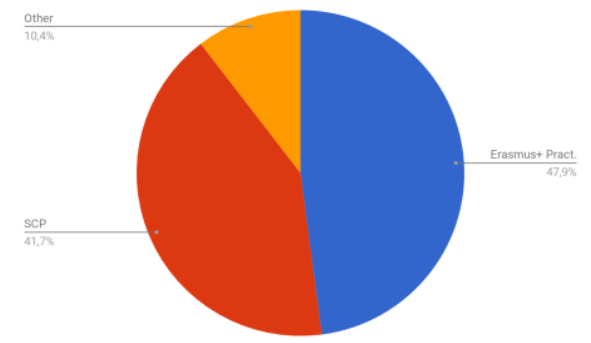

Figure 10. Access to the International Internship Program

\section{Average grade of the studies}

The largest group is that of students with average grade between 2.51 and 3 (in a 0 to 4 scale), quite a $40 \%$.

In the lowest range: a $14,6 \%$ for students with a grades between 0 to 2 and also for students with 2,01 to 2,50; there is approximately an $30 \%$ of the respondents.

In the highest range, from 3,01 to 3,50 a $23 \%$ of the students and more than 3,51 until 4 , an $8 \%$ that means an $31 \%$ of the total student All of them are a very good students and some of them with a very good grades.

\section{Date of finalization of the internship}

One of the items of the survey were related to the date of finalisation of the internship and the students affirmed that more than half of the internships $(52 \%)$ were finished less than one year before the survey. The other half were distributed by two options, $31,3 \%$ between one and two years ago and the $16,7 \%$ more than three years ago. In summary, the most frequent internships had the following features: not paid, for a period of 6 months or shorter, done in a EU company (3 out 4) and in a non-multinational company. Internships in a Public Administration were chosen by 3 out 5 respondents. Erasmus+ Practices Programme internships 
are the most frequent and Germany, France and UK are the most popular destinations among students.

\section{B. Internships and employability}

The second group of items are related to international internships and their effect on the employability. Many studies have been done in this aspect. At the end of the process, employability is the main objective for the majority of the trainees. As Tymon (2013) says in this work, for a student employability is a short-term means to an end, being about finding a job, any job, or employment. In contrast to the literature definitions which is more concerned with a longer-term quality and sustainability of graduate-level employment. In the present work, we do not make this distinction, mostly because we were at the end of a very severe economic crisis in Spain.

The objective was to know the employment situation of the students at the end and after doing the international internship. The questions were related to two different possible situations: a) Situation at the end of the internship and its length: labour contract offered, practices extension offered, or no offer. b) Current situation: working, still doing an internship or searching for a job.

\section{Situation at the end of the internship and its length.}

Continuation of the internship: Two out of five interns continued after the initial term, either with a job offer in form of permanent contract $(6,3 \%)$, contract for more than one year $(6,3 \%)$ and contract for less than one year $(10,4 \%)$, or with an internship extension (16,7\%). More than half $(54,2$ $\%$ ) of the sample did not receive any offer. A 6,3\% had other situation and it is an student that had not been finished their studies yet. It is remarkable that only less than half of the respondents had a job offer or an extension of the practices. That have some relations to the point 5.1.e., that half of the internships were finished less than one year before the survey was done.

More detailed information can be seen in the Figure 1.11, below.

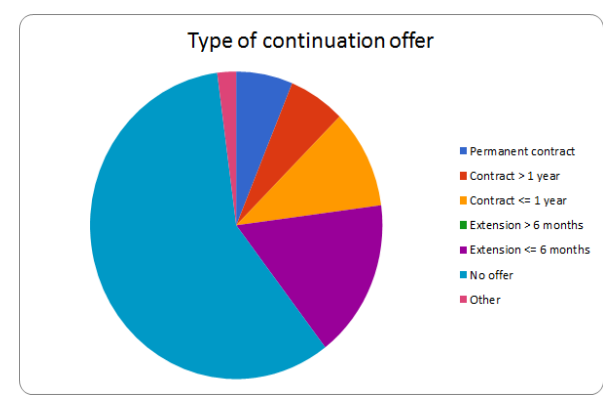

Figure 11. Situation at the end of the internship

\section{Current situation}

The current employment status indicates that three out of eight employed respondents work for a company, with international company workers doubling those in local companies.
According to the Figure 1.12 below, 12,5\% of the respondents were searching for job at the moment of the survey, and $41,7 \%$ were in a non specific situation at this time, in total is more than half of the respondents $(54,2 \%)$ All of these students are still studying a $\mathrm{PhD}$, Master or other studies, except one who is working in a Latin American company. That is the first important result.

An $8,3 \%$ were still doing an international internship. The rest $(35,4 \%)$ had different options of employment, in other words that is: international company, in Europe and in Spain both an $8,3 \%$, in a Catalan company a $6,3 \%$, and a local company a $12,5 \%$. The most significant result, in our opinion is the lack of continuation for more of the half of the respondents and a low percentage for self-employed students. See Figure 1.12.

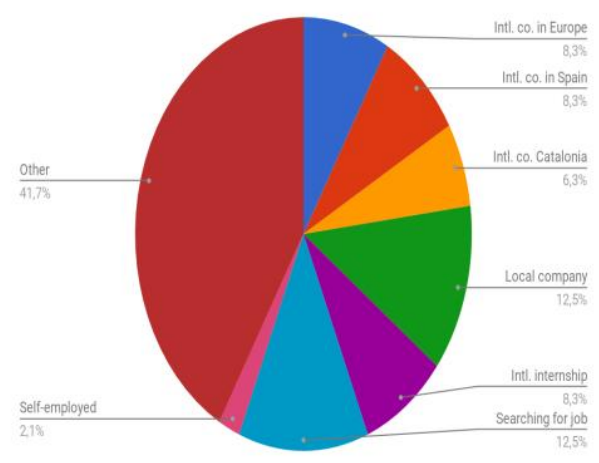

Figure 12. Current employment status

This result indicate that the majority of them followed the International Internship by studying a postgraduate studies. More information are not available related the motivation of these students, and can be for lack of job expectations (Spanish economic crisis) or because it was part of theirs formation process.

3. The features of the employability for student which the current situation is employed

In the case in which the current situation is employed, we can find four possible aspects to be analysed:

a) Firstly, the study analysed the "current" students' situation. There were three option of situation, the type of contract, if they have a permanent or temporary contract and other job situations.

The results show that one fourth $(28,6 \%)$ of employed respondents work with a permanent contract, and a $42,9 \%$ with temporal contract. The rest is not specified. The temporary contract is close to the half of the population.

A more detailed analysis for the "Other" answer shows that 8 students answered this question without having a contract. More specifically the majority were still studying or having a some type of fellowship, and in this last case it was a temporary contract. 


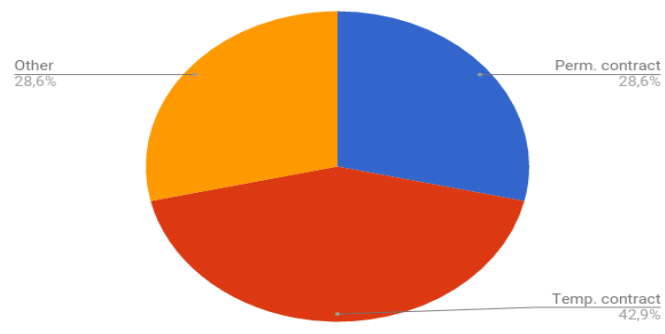

Figure 13. Type of contract for employed students

b) The second aspect analysed is about the type of the company which they worked, distinguishing between local company, national or European company

According to the Figure 1.12 above, a $35,4 \%$ of the respondents had different options of employment, in other words that is an $8,3 \%$ were working in an European company, an $8,3 \%$ in a Spanish company, and a $8,3 \%$, in a Catalan company, and $12,5 \%$ in a local (village) company. In other words, a $20 \%$ were working close to their family environment.

c) The third item were related to if they were self-employed or working in their own company.

Only a 2,1\% were self-employed, according to the Figure 1.12 above. It is not an option for the majority of the UPF students and as well it has not been promoted by the academic institution, and they did not have any help for this option at this time.

d) The fourth and last item was if the student was working is in the same company as in the internship.

Only one out of six employed $(15,2 \%)$ respondents said that they are working for the same company as the internship. See Figure 1.14, below.

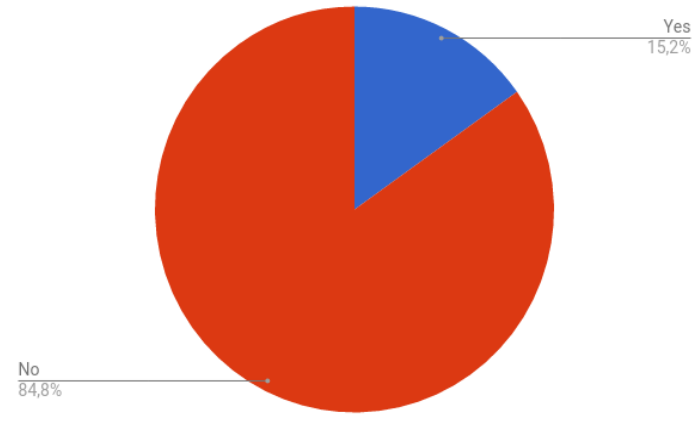

Figure 14. Students percentage of working in the same company as the internship

Concerning the relationship between internships and employability, taking into account that the e-survey was conducted in a period in which the economic crises was still in a deep phase, the answers to the questionnaire indicate in relation to the continuation of the internship that only $46 \%$ of the respondents had an offer after the internship. $17 \%$ of these respondents had an internship extension, and the rest a labour contract and other situations $(30 \%)$. A permanent labour contract and a contract for more than 1 year was offered to $12,6 \%$ of the respondents, in the same proportion $(6,3 \%)$. A contract for a duration of less than 1 year was offered to $10,5 \%$ of the respondents and for the rest there is no specification. These results will have to be contrasted with a new e-survey at the beginning of the twenties of the XXI century.

The employability situation of the respondents when the e-survey was done was as follows: a) three out of eight employed respondents work for a company, with international company workers doubling those in local companies, possibly because of the international experience, b) one fourth of employed respondents work with a permanent contract.

Only one out of six employed respondents works for the same company as the internship. This can mean that internships, at this time, are not a major way of labour insertion, but three out of four employed respondents consider their international internship was useful to have a job.

On the relationship between current job and internship, five out of eight employed respondents consider their studies were connected or very connected to their work and three out of four employed respondents consider their international internship was useful. This is a very good outcome.

4. Subjective items and assessment of their practices

The following group of items were dedicated to subjective items relating the current activity and the skills and knowledge received in the academic institution. As well as to know if there was any relation between their perception and the academic level of the studies done measured by the average grades acquired. In this section the items are related to a perceptions and opinions of the students. There is no difference in the results of the time in they have finished the international internship.

In the Figure 1.15 shows that half of the internships were finished less than one year before the survey was administered, and for this recent internships it is not easy to have a continuation of their practices. In another words, they could have a recent remains of the internship for a half of the respondents.

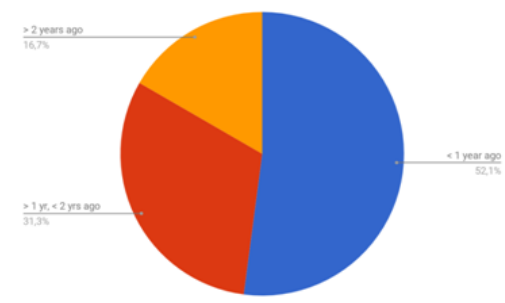

Figure 15. Date of compilation the internship

Four type of questions were in the e-survey in this topic. The first one was (a) the connexion between studies and current work. Secondly, (b), the

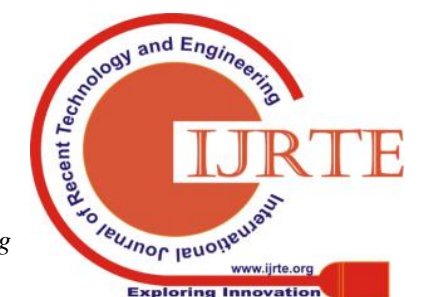


usefulness of international internship in finding the current work. Following by (c) the soft skills developed during the international internship that are applied in the current work, and fourthly (d) a question more subjective and a measure of they global self-assessment during the internship.

a) If employed, degree of connection between studies and current work: Five out of eight employed respondents consider their studies were connected or very connected to their work. See Figure 1.16 below.
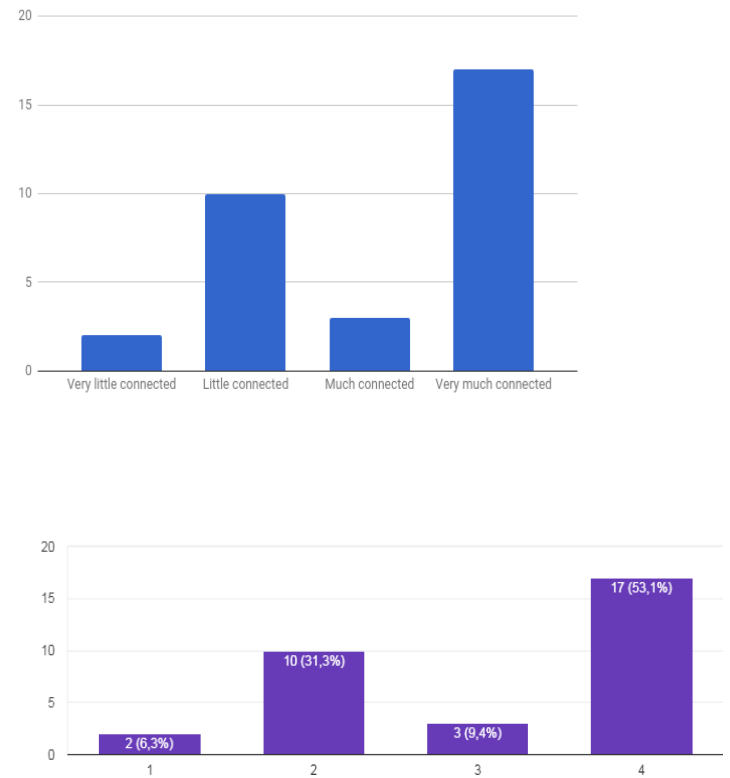

Figure 16. Degree of connection between studies and work for employed students

b) the usefulness of international internship in finding the current work

The results was unquestionable: $75 \%$ of the answers that affirms the importance of the international internship to find a new work. The rest could be students that had other priorities like followed studying

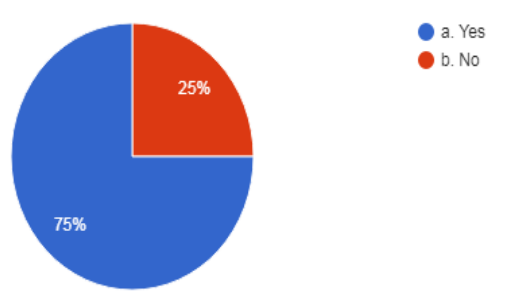

c) Global self-assessment of the internship done. In a 0 to 10 scale, the average self-assessment of international internship is $7.02(\mathrm{SD}=2.17)$.

Global self-assessment of internship: In a 0 to 10 scale, the average self-assessment of international internship is $7.02(\mathrm{SD}=2.17)$

The students' global self-assessment of the international practices is quite high but quite a non negligible number of them said that they didn't assess as a good experience.

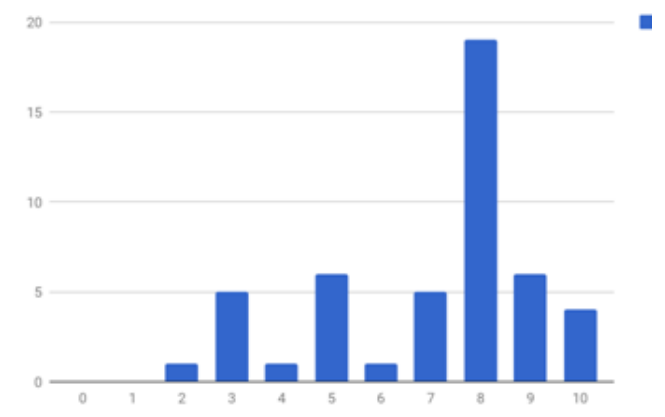

Figure 17. Global self-assessment of internship

The average academic grade of the students participating in the e-survey

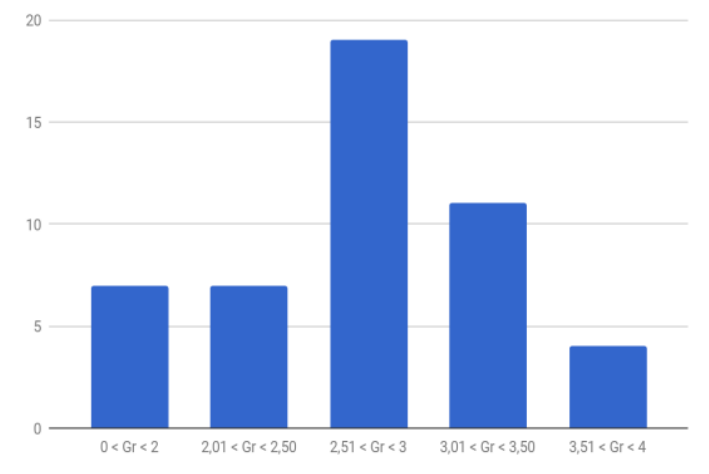

Figure 18. Average grade of studies

Average grade of studies: The largest group is that of students with average grade between 2.51 and 3 (in a 0 to 4 scale)

The answers to the average grade of the studies shows that the largest group of students have a superior level than 2,51 in a $0-4$ scale, and that means that they have had a good score grades.

In summary, and in relationship between internships and employability, and taking into account that e-survey was conducted in a period in which the economic crises were still in a deep phase, the answers to the questionnaire indicate than in relation to the continuation of the internship, only 46 $\%$ of the respondents had an offer after the internship. The $17 \%$ of these respondents had an internship extension, and the rest a labour contract and other situations (30\%). A permanent labour contract and a contract for more than 1 year was held to a $12,6 \%$ of the respondents, in the same proportion $(6,3 \%)$. A contract for a duration less than 1 year was offered to a $10,5 \%$ of the respondents and the rest there is no specification. These results have to be contrasted to a new e-survey at the beginning of the twenties of the XXI century.

The employability situation of the respondent when the e-survey was done were the following: a)three out of eight employed respondents work for a company, with international company workers doubling 
those in local companies, possibly because its international experience (??); b) One fourth of employed respondents work with a permanent contract.

Only one out of six employed respondents works for the same company as the internship, that can mean that internships, at this time, were not a big way of labour insertion, but three out of four employed respondents consider their international internship was useful to have a job.

The relationship between current job and internship, five out of eight employed respondents consider their studies were connected or very connected to their work and three out of four employed respondents consider their international internship was useful. That are a very good answers.

\section{INTERRELATIONS BETWEEN VARIABLES}

The lack of a number of observations has been a great difficulty to find significant results applying econometrics models. Because that some interrelations of variables have been done. The results are presented in four associations of variables and there are the following. Firstly, we investigate is exists any correlation between the average grade of the student and the internship continuation, secondly the average grade to the student current situation. A second group of interrelations has been done taking gender into account with the same two variables: internship continuation and current situation. The results are described in the following four sections.

\section{Internship continuation vs Average grade}

The research question was if students with better grades have had more options for employability. That is if the grade influenced the internship continuation. The results indicate that the Correlation between internship continuation offer and average grade is weak.

The students with better grades was the one who acquired more permanent contract and affirmed received "other" options in major proportion, and the students with lower grades did not received any offer or transitory offer less than 6 months. In the middle of this two extremes there are students with average grades and temporary contracts (more and less than 6 months) in proportion to the average grade, as is seen in colour turquoise and purple in the bars.

For more detailed information, see Figure 1.19 below.

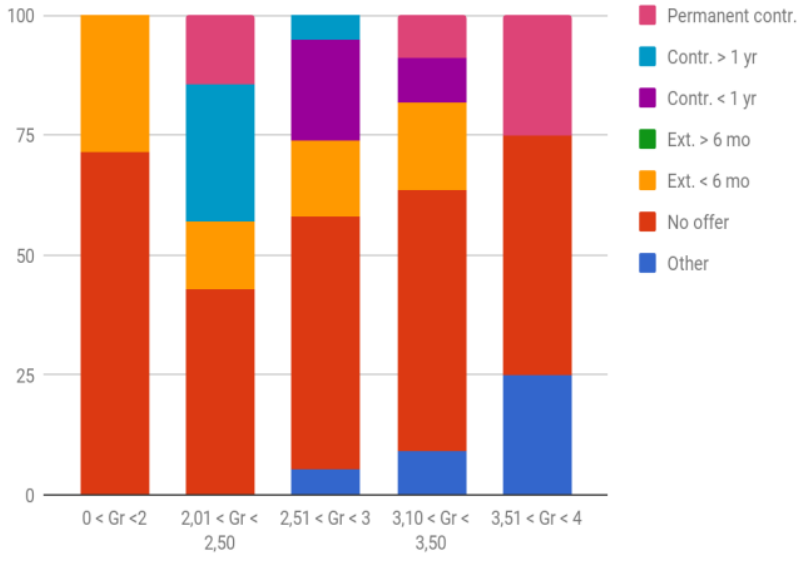

Figure 19. Interrelation between Internship continuation vs Average grade

\section{Current status vs Average grade}

In general, students with higher grade are more likely to be currently employed, but there is not a strong trend in a similar way as in the previous relationship, compare to Figure 1.19.

The students with higher average degree are not searching for work and are having work in International companies in Europe than the rest of students. In the other way around, the students with lowest average grades are the only who are self-employed for this study.

No explicit rules can be expressed seeing the result obtained, due to the low observations obtained.

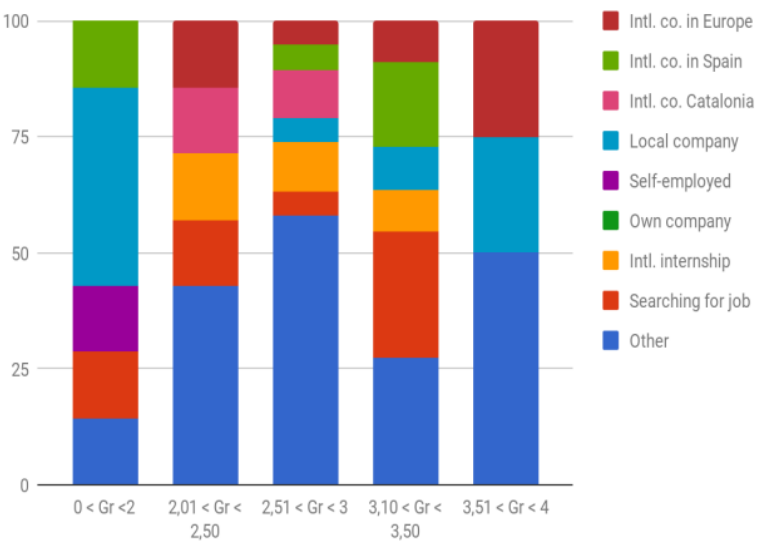

Figure 20. Relations between Current status vs Average grade

\section{Internship continuation vs Gender}

A second group of interrelations have gender as a new variable and is correlated with internship continuations and current status. The results shown that there are no significant differences with respect to gender, except in short term contracts, all contracts of duration shorter than 1 year were offered only to female students. See Figure 1.21 below. 


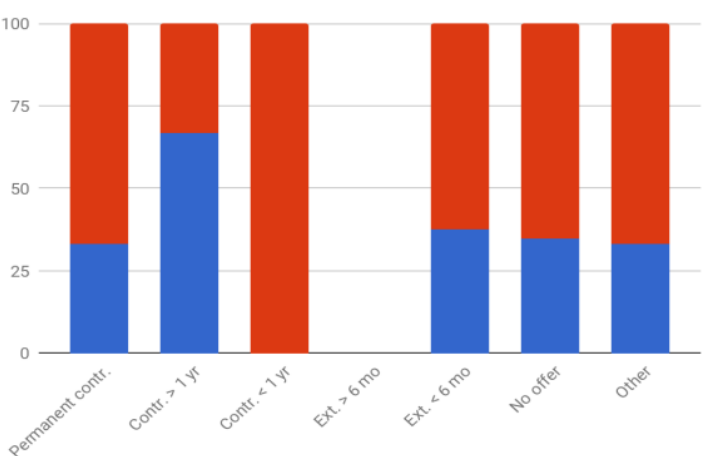

Figure 21. Relations between Internship continuation and Gender

\section{Current status vs Gender}

The correlation between current status and gender do not give any great results. The respondents were distributed on $33 \%$ males and $66 \%$ females. The result are consistent with this proportion, except for three cases: a) only females are as a self-employed, b) $60 \%$ of males are searching for job and c) there is a $50 \%$ of males and females having work in international companies in Europe, at is shown in Figure 1.22 below.

There are no significant differences, taking into account that, except for the "Other" category, all groups are of 6 members or less.

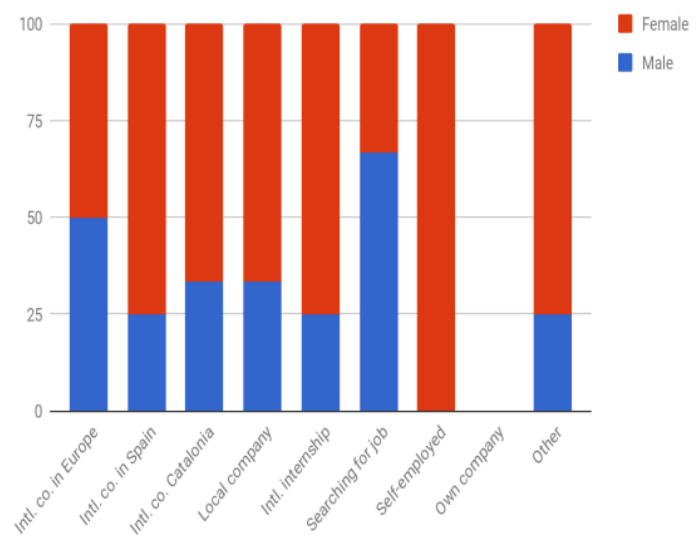

Figure 22. Relations between Current status and Gender

\section{OPEN QUESTIONS}

There were three open questions in the survey finishing the questionnaire. We were interested in knowing any further information that was not collected in the questionnaire and could be interesting for knowing something more about their experience, in the same line that previous e-surveys, which allowed the student to explain everything that sometimes is difficult to pick up asking closed questions.

We were not prepared the questionnaire to analyse the uses of soft versus hard skills as Andrews and Higson (2008) done to business students, we were more interested in knowing the effect of being abroad.

\section{First open question}

In the first open question, we wanted to know what the students considered the most valuable aspect of their stay in a foreign institution (company). The question was formulated as follows:

In your view what is the most remarkable input that the knowledge of international companies has contributed to your training?

A total of 27 students answered this question, and the summary of their answers is: 17 of them $(63 \%)$ said that improving languages and/or improving vocabulary was one of their main goals. For 15 out of $27(55,5 \%)$ the answer was to have international work experience and/or professionalism; for 7 out of 27 (26\%), to meet people and doing networking, and the same percentage for having international culture experience. See the answers in Table 1, below. The answers are categorised in four groups: Improving Languages and Vocabulary, usually is one of the most common motivation, secondly: Networking ( to meet people from other countries); both options are shared with the mobility programmes. To work in another country it can help to amplify the knowledge of another culture and more specifically to acquire International Work Experience, that is properly the effect of the International Internship. In Other Comments.

\begin{tabular}{|c|c|c|c|c|c|}
\hline $\begin{array}{l}\text { Stude } \\
\text { nt }\end{array}$ & $\begin{array}{l}\text { Impr } \\
\text { ovin } \\
\text { g } \\
\text { lang } \\
\text { uage } \\
\text { s/ } \\
\text { Impr } \\
\text { ovin } \\
\text { g } \\
\text { voca } \\
\text { bula } \\
\text { ry }\end{array}$ & $\begin{array}{l}\text { Meet } \\
\text { peopl } \\
\text { e from } \\
\text { other } \\
\text { count } \\
\text { ries/ } \\
\text { Netw } \\
\text { orkin } \\
\text { g }\end{array}$ & $\begin{array}{l}\text { Internat } \\
\text { ional } \\
\text { work } \\
\text { experie } \\
\text { nce/ } \\
\text { Professi } \\
\text { onalism }\end{array}$ & $\begin{array}{l}\text { Intern } \\
\text { ational } \\
\text { cultur } \\
\text { e } \\
\text { experi } \\
\text { ence }\end{array}$ & $\begin{array}{l}\text { Other } \\
\text { Comment } \\
\text { s }\end{array}$ \\
\hline 1 & $\boldsymbol{v}$ & & $\boldsymbol{V}$ & & $\begin{array}{l}\text { having an } \\
\text { opportunit } \\
\text { y to work } \\
\text { in a } \\
\text { fashion } \\
\text { company }\end{array}$ \\
\hline 2 & $\boldsymbol{v}$ & $\boldsymbol{V}$ & & & $\begin{array}{l}\text { interestin } \\
\mathrm{g} \text { projects } \\
\text { and } \\
\text { challenge } \\
\mathrm{s}\end{array}$ \\
\hline 3 & $\boldsymbol{v}$ & $\boldsymbol{v}$ & $\boldsymbol{v}$ & $\boldsymbol{V}$ & $\begin{array}{l}\text { Hospitals } \\
\text { in UK }\end{array}$ \\
\hline 4 & & & $\boldsymbol{V}$ & $\boldsymbol{V}$ & \\
\hline
\end{tabular}




\begin{tabular}{|c|c|c|c|c|c|}
\hline 5 & $\checkmark$ & & $v$ & & $\begin{array}{l}\text { that } \\
\text { contribute } \\
\mathrm{d} \text { most } \\
\text { when } \\
\text { applying } \\
\text { for } \mathrm{PhD} \\
\text { positions }\end{array}$ \\
\hline 6 & & & & & $\begin{array}{l}\text { analytics, } \\
\text { structure, } \\
\text { logic } \\
\text { thinking } \\
\text { and } \\
\text { marketing }\end{array}$ \\
\hline 7 & $v$ & & $v$ & $v$ & $\begin{array}{l}\text { widening } \\
\text { of } \\
\text { technical } \\
\text { skills } \\
\text { relevant } \\
\text { to my } \\
\text { field }\end{array}$ \\
\hline 8 & $\checkmark$ & & & & \\
\hline 9 & & & $\checkmark$ & & \\
\hline 10 & $v$ & & & & $\begin{array}{l}\text { dealing } \\
\text { with angry } \\
\text { citizens }\end{array}$ \\
\hline 11 & $\checkmark$ & & $\checkmark$ & & \\
\hline 12 & $v$ & & $\checkmark$ & & new skills \\
\hline 13 & & & $v$ & & $\begin{array}{l}\text { guidance } \\
\text { for my } \\
\text { specializa } \\
\text { tion }\end{array}$ \\
\hline 14 & & $\checkmark$ & & & \\
\hline 15 & & $\checkmark$ & $\checkmark$ & & \\
\hline 16 & $\checkmark$ & & $\checkmark$ & & \\
\hline 17 & & & & & $\begin{array}{l}\text { apply for } \\
\text { my } \\
\text { current } \\
\mathrm{PhD} \\
\text { position }\end{array}$ \\
\hline 18 & $v$ & $\checkmark$ & & & \\
\hline 19 & & $\checkmark$ & $\checkmark$ & & \\
\hline 20 & $\checkmark$ & & & $v$ & \\
\hline 21 & $v$ & $\checkmark$ & $r$ & & \\
\hline 22 & & & $v$ & & $\begin{array}{l}\text { How to } \\
\text { interact in } \\
\text { a business } \\
\text { environm } \\
\text { ent } \\
\text { Improvem } \\
\text { ent of } \\
\text { organisati } \\
\text { on, }\end{array}$ \\
\hline
\end{tabular}

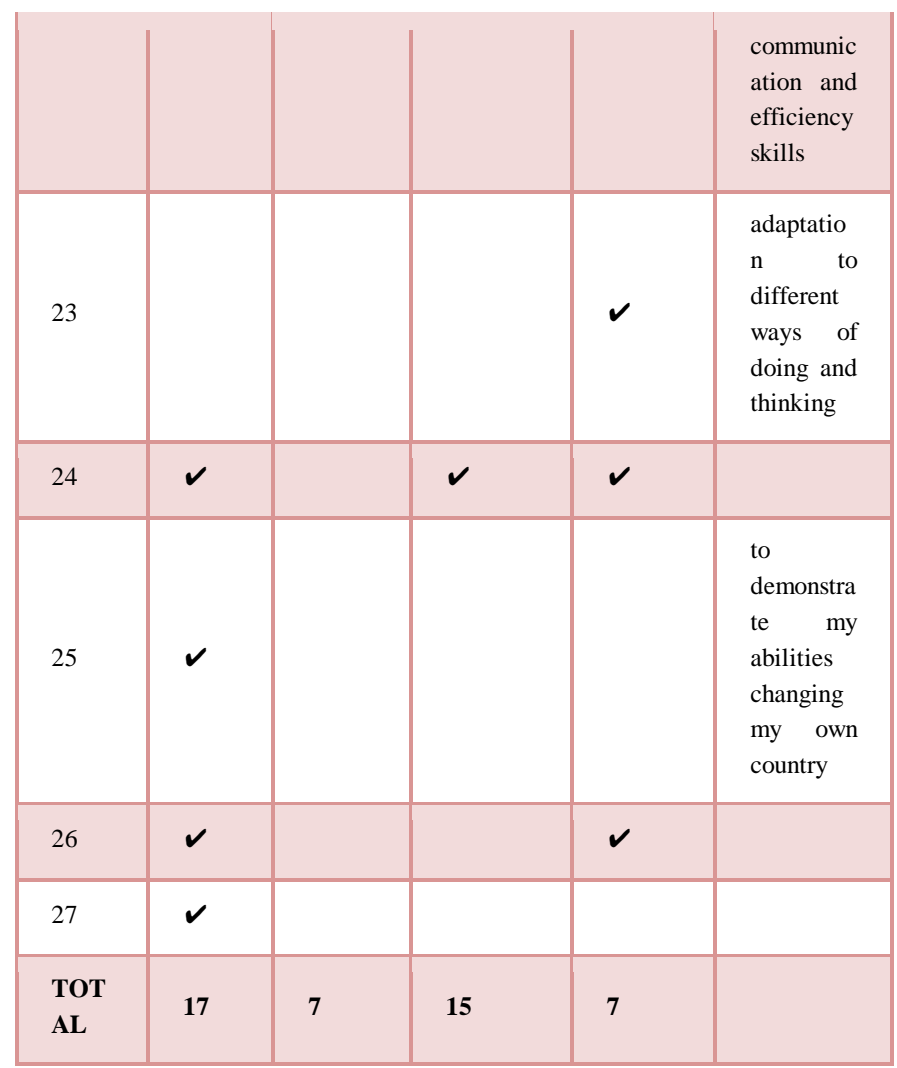

Table 1. First Free Open Question. Most remarkable inputs given by the companies

\section{Second open question}

A second open question was intended to gather the student considered most relevant as a contribution to his institution in which he practiced.

The second Free Open Question was written as follows:In your view what is your main contribution to the company where You did your practices?

Three possible answers were: professionals skills, personal skills and other, and, as well, an free open comments. A total of 22 students answered this open question. In general terms, as a summary, the results were the following. A 15 up to 22 $(68 \%)$ affirmed that the main contribution to the company were professional skills, 6 o the total of the students (27\%) noted personal skills and 4 up to 22, (18\%) other contributions. See Table 2, below.

\begin{tabular}{|c|c|c|c|c|}
\hline Student & $\begin{array}{c}\text { Profession } \\
\text { al } \\
\text { skills }\end{array}$ & $\begin{array}{c}\text { Personal } \\
\text { skills }\end{array}$ & Other & Comments \\
\hline 1 & & $\checkmark$ & & $\begin{array}{l}\text { relationship to my } \\
\text { country - fresh point } \\
\text { of view - enthusiasm } \\
\text { and energy }\end{array}$ \\
\hline 2 & & & & Student \\
\hline 3 & $\nu$ & & & $\begin{array}{c}\text { To gain more } \\
\text { business in the EU } \\
\text { policy area }\end{array}$ \\
\hline 4 & $\nu$ & $\checkmark$ & & \\
\hline $\begin{array}{l}P u \\
B l u \\
\&\end{array}$ & $\begin{array}{l}\text { led By: } \\
\text { yes Intelli } \\
\text { uces Publ }\end{array}$ & Engin & & \\
\hline
\end{tabular}




\begin{tabular}{|c|c|c|c|c|}
\hline 5 & $\checkmark$ & & & $\begin{array}{l}\text { Problem Solving } \\
\text { Skills }\end{array}$ \\
\hline 6 & & & $\boldsymbol{v}$ & $\begin{array}{c}\text { Relationship to my } \\
\text { country }\end{array}$ \\
\hline 7 & $\checkmark$ & & & Laboratory work \\
\hline 8 & & & $\boldsymbol{v}$ & Fresh air \\
\hline 9 & & & $\boldsymbol{v}$ & $\begin{array}{l}\text { We solved their lack } \\
\text { of personnel during } \\
\text { the summer time }\end{array}$ \\
\hline 10 & $\checkmark$ & & & $\begin{array}{c}\text { Help in the } \\
\text { development of the } \\
\text { project }\end{array}$ \\
\hline 11 & $\checkmark$ & $\checkmark$ & & $\begin{array}{l}\text { Networking, another } \\
\text { view of the field }\end{array}$ \\
\hline 12 & $\checkmark$ & & & $\begin{array}{c}\text { Knowledge in } \\
\text { various disciplines } \\
\text { (philosophy, politics } \\
\text { and economics) that } \\
\text { I could apply in my } \\
\text { work. }\end{array}$ \\
\hline 13 & $\checkmark$ & & & Research \\
\hline 14 & $\checkmark$ & & & $\begin{array}{l}\text { Different point of } \\
\text { view to solve } \\
\text { problems, free } \\
\text { employees }\end{array}$ \\
\hline 15 & & & $\checkmark$ & A very cheap worker \\
\hline 16 & $\checkmark$ & & & $\begin{array}{c}\text { Software } \\
\text { development }\end{array}$ \\
\hline 17 & $\checkmark$ & $\checkmark$ & & $\begin{array}{l}\text { Problem solving } \\
\text { abilities, technical } \\
\text { experience, good } \\
\text { theoretical } \\
\text { knowledge }\end{array}$ \\
\hline 18 & $\checkmark$ & & & $\begin{array}{l}\text { The published } \\
\text { (internal) reports I } \\
\text { contributed to on } \\
\text { economic analysis }\end{array}$ \\
\hline 19 & $\checkmark$ & & & $\begin{array}{l}\text { Different point of } \\
\text { view to solve } \\
\text { problems }\end{array}$ \\
\hline 20 & $\checkmark$ & & & $\begin{array}{c}\text { Different point of } \\
\text { view, information } \\
\text { about how we solve } \\
\text { some situations in } \\
\text { my Hospital }\end{array}$ \\
\hline 21 & $\checkmark$ & $\checkmark$ & & $\begin{array}{l}\text { Different point of } \\
\text { view to solve } \\
\text { problems and a more } \\
\text { dynamic mood of } \\
\text { working }\end{array}$ \\
\hline 22 & & $\checkmark$ & & Languages \\
\hline TOTAL & 15 & 6 & 4 & \\
\hline
\end{tabular}

Table 2. Second Free question. Students main contribution to the company/institution

The more interesting comments were related to "a different point of view of ..." for 5 up to $22(22,7 \%)$ of the respondents. Three of the respondents answers were related to cheap labor force, for example: "a very cheap worker" , "to solve their personnel summer problems", "free employees"... maybe because there was an internship not remunerated.

Finally, some positive comments as: "fresh point of view enthusiasm and energy", "fresh air", "Networking, another view of the field", "Knowledge in various disciplines (philosophy, politics and economics) that I could apply in my work".

\section{Third open question}

Finally, a section was left for general comments, suggestions or everything that the student considered opportune to tell it to us. Only 6 students used this option. Although the comments are not significant from the surveyed population who responded to the e-survey, they are understood to be those who are more interested in knowing what has not been graded at all, or a lot. Considering the responses very interesting and have the responsibility of those responsible for the program.

There was a certain discomfort in feeling like a cheap labour force, which manifests in many comments, despite the experience itself being considered valuable and relevant to his career. A summary in the following table (Table 3) can be read. 


\begin{tabular}{|c|c|}
\hline Student & Comments \\
\hline 1 & $\begin{array}{l}\text { Maybe in Q10 I would add between } 2 \text { and } 3 \text { years. Also, } \\
\text { I give here my experience in my } 2 \text { nd internship (once I } \\
\text { finished my studies), but while coursing my MA double } \\
\text { degree in Germany I also had an Erasmus+ praktikum, } \\
\text { but the survey only allowed me to talk about one } \\
\text { situation. I don't know if this comment helps, but in any } \\
\text { case, good luck with the respondent rate;) }\end{array}$ \\
\hline 2 & $\begin{array}{l}\text { I think internships like that should be more incentive } \\
\text { from our side and more help is required in terms of } \\
\text { finding a position that can be also paid. Because } \\
\text { Erasmus+economical contribution does not even allow } \\
\text { You to pay rent in some countries and some employers } \\
\text { will not consider helping You economically at all. }\end{array}$ \\
\hline 3 & $\begin{array}{l}\text { Assuming all the tasks of a public servant without being } \\
\text { compensated was frustrating. The tasks we were } \\
\text { ordered to do did not respond to our level and field of } \\
\text { studies (they were mostly administrative support to } \\
\text { common procedures) }\end{array}$ \\
\hline 4 & $\begin{array}{l}\text { International internship is a great experience but } \\
\text { conditions are horrible, neither economic contribution } \\
\text { neither social security, neither the time one is working } \\
\text { for free even there is a contract, it doesn't count like job } \\
\text { so there is not contribution with the Spanish state. }\end{array}$ \\
\hline 5 & $\begin{array}{l}\text { The internship was very positive, the only big issue is } \\
\text { that the resolution of the scholarship (Erasmus) came } \\
\text { AFTER I started the internship. Thus, I had to make sure } \\
\text { I could have the money in advance. }\end{array}$ \\
\hline 6 & $\begin{array}{l}\text { Any kind of internship supported by the university } \\
\text { should be paid }\end{array}$ \\
\hline
\end{tabular}

Table 3. Third Open Question. Comments and suggestions (literal transcription).

By the other hand some positive sentences were: " International internships is a great experience... ", "The internship was very positive".

\section{IMPLICATIONS OF THE STUDY}

A The present research is a work in progress and the expected results are to know the evolution of the surveyed graduates after one year or more of their international internships.

The goal of the questionnaire is to find out which is the evolution of the factors that contribute to a successful international traineeship and its employment. The first results are expected to be available at the beginning of 2018.

Given the scarce number of studies on work placements abroad, this work will contribute to a better understanding of the experiences of students coming from a South European university and their expectations of finding a job in a foreign country (Pedro and Franco, 2015). For a great number of undergraduate students this is currently one of their main goals (Van Mol, 2016).

Future continuation of this work will consist in comparing these results with other universities from the same geographical area, there is a work in process.

\section{LIMITATIONS}

The e-survey rate responses are usually very low, is acceptable a $10 \%$ of responses . It is not the case, the found another limitation that is the low number of individuals of the population, not a lot of the UPF students choose this type of mobility options, maybe it is not well known by them.

The lack of enough observations did not allow to use a more accurate statistical procedures and the results of the current work can be an exploratory design for a future research. The following step in this research line is to use an official database from the Catalan Autonomous Government that will help to answer the research questions for the Catalan Higher Education students population.

\section{CONCLUSIONS}

Currently, landing and take-off processes are taken with great care by the leading universities of our region. In particular, the transition from the academic world to the workplace has been done through professional practices that gave the minimum experience necessary to make the transition smoothly. The globalization, which includes university students, has led to the emergence of international practices with a thrust and with increasing interest on their part. The stay in a foreign company / institution offers even more experience to be able to make the move to international companies and institutions.

This process between international practices and the world of work has been very little studied in today's literature, although it is one of the benchmarks of the internationalization of nationalities, much more specifically for the Spaniards.

International internships, under the Erasmus + Practicum program, have been carried out since 2010, both for postgraduates and for undergraduate students, in which students have taken part individually.

Besides, there are no studies done internationally, which is amazing, if we consider the interest that the topic arouses at the congress level.

- This research is work in progress to know the evolution of graduates after one year of finishing the internship

- Outcome of the study will be helpful in knowing which factors contribute to successful international internships and employment

- Future work: compare the results with other universities in the same geographical area.

\section{REFERENCES}

1. Alemany, J., Perramon, X. \& Panadés, L. (2014) The internship in the EHEA adaptation process. The UPF's first year of graduates' opinion. Revista de Docència Universitaria. Vol 12 (4), Septiembre-Diciembre 2014, 115-139 ISSN: 1887-4592. 
2. Andrews, J., \& Higson, H. (2008). Graduate employability, 'Soft Skills' versus 'Hard' Business Knowledge: A European study. Higher Education in Europe, 33(4), 411-422. https://doi.org/10.1080/03797720802522627.

3. Capa, P. (2016). The employability effects of short-term national and international internships on the evaluation of business students' applications to an-entry-level marketing position. Master Dissertation, Porto University Deakin, H. (2012). Erasmus Student Work Placement Mobility. Ph.D. thesis, Loughborough University.

4. European Commission (2017). 2018 annual work programme for the implementation of 'Erasmus+': the Union Programme for Education, Training, Youth and Sport - C(2017) 5652. Available at https://ec.europa.eu/education/sites/education/files/c-2017-5652 en.pdf.

5. Griffiths, T., Guile, D. (2003). A connective model of learning: The implications for work process knowledge. European Educational Research Journal, 2, 56-73.

6. Knipprath, H., De Rick, K. (2014). The effect of educational career and job characteristics on the competence level of highly-educated employees, presented at SIG 4 \& SIG 17 EARLI Conference, Leuven (BE).

7. Kosnik, R.D., Tingle, J.K. and Blanton, E.L. (2013). Transformational learning in business education: the pivotal role of experiential learning projects. American Journal of Business Education, 6(6):613-630.

8. NAFSA (2014). Developing International Internship programs.http://www.nafsa.org/uploadedFiles/Chez_NAFSA/Find_Resou rces/Supporting_Education_Abroad/intl_internship_program.pdf (January, 2019)

9. Pan, B. (2010). Online Travel Surveys and Response Patterns. Journal of Travel Research, 49(1):121-135.

10. Pedro, E., Franco, M. (2015). The importance of networks in the transnational mobility of higher education students: attraction and satisfaction of foreign mobility students at public university. Studies in Higher Education, 1-29.

11. Sanahuja Vélez, G., \& Ribes Giner, G. (2015). Effects of busines internships on students, employers, and higher education institutions: A systematic review. Journal of Employment Counseling, 52(3), 121-130.

12. Sheehan, K. B., McMillan, S. J. (1999). Response Variation in E-Mail Surveys: An Exploration. Journal of Advertising Research, 39(4):45-54.

13. Toncar, M.F. and Cudmore, B.V. (2000). The overseas Internship Experience. Journal of of Marketing Education, 22(1), 54-63. DOI: $10.1177 / 0273475300221007$

14. Tran, L. T., \& Soejatminah, S. (2017). Integration of Work Experience and Learning for International Students: From Harmony to Inequality. Journal of Studies in International Education, 21(3), 261-277.

15. Tymon, A. (2013). The student perspective on employability. Studies in Higher Education, 38(6), 841-856.

16. Tynjälä, P. (2008). Perspectives into learning at the workplace. Educational Research Review, 3, 130-54.

17. Virtanen, A., Tynjälä, P., Eteläpelto, A. (2012). Factors promoting vocational students' learning at work: study on student experiences. Journal of Education and Work.

18. Van Mol, C. (2016). Migration aspirations of European youth in times of crisis. Journal of Youth Studies, 1-18

19. Vriens, M., Achten, M., Op de Beeck, I., \& Van Petegem, W. (2011) Virtual mobility in international work placements. In Learning and Sustainability. The New Ecosystem of Innovation and Knowledge. Book of Abstracts. European Distance and E-Learning Network. Youthforum.org (2018). The European Parliament bans unpaid internships. Available at: https://www.youthforum.org/european-parliament-bans-unpaid-internship s (retrieved 13 July 2018).

20. Vygotsky, L. S. (1980). Mind in society: The development of higher psychological processes. Harvard University Press.

21. Zhang, X. (2012). Discussion on international internship and intercultural competence from a perspective of higher educational internationalization A case study of the program work and travel USA. Cross-Cultural Communication, 8(5), 62 . 